\title{
Polemiczny charakter wykorzystania greckiego słownictwa misteryjnego przez tłumaczy Septuaginty
}

\author{
Polemic Character of the Use of the Greek Mysteric Vocabulary \\ by the Translators of the Septuagint
}

PAWE $\longleftarrow$ LASEK

Katolicki Uniwersytet Lubelski Jana Pawła II

xplasek@wp.pl, ORCID: 0000-0002-6498-9132

\begin{abstract}
Streszczenie: Celem artykułu jest analiza występowania słownictwa misteryjnego obecnego w tłumaczeniu Septuaginty. W czasie, kiedy to tłumaczenie powstawało, greckie kulty misteryjne były bardzo popularne. Pewna ich część pozostawała tajemnicą, ale słownictwo, symbolika i część ich ideologii były szeroko znane, także izraelskiej wspólnocie żyjącej w diasporze aleksandryjskiej. Nie jest zatem niczym dziwnym, że w tekście LXX spotykamy słowa związane z kultami misteryjnymi. Tym, co jest zaskakujące i co zachęca do podjęcia badań nad tym zagadnieniem jest to, że w LXX są miejsca, gdzie greckie słowa związane z kultami misteryjnymi tłumaczą słowa hebrajskie w sposób niewłaściwy oraz zmieniają znaczenie i wymowę tłumaczonego tekstu. Z taką sytuacją mamy do czynienia np. w księdze Ozeasza, gdzie spotykamy misteryjne słowa „światło” i „wiedza”, podczas gdy tekst hebrajski przedstawia obrazy rolnicze, oraz w księdze Zachariasza, gdzie hebrajskie słowo "mirt” jest tłumaczone jako „góra”, a słowo „bocian” jako „dudek”. Artykuł podejmuje analizę takiego postępowania tłumaczy LXX oraz motywów ich działania. Możemy tu zaobserwować polemikę z kultami misteryjnymi, prowadzona na dwa sposoby: 1) przez prezentowanie kultów misteryjnych i ich uczestników w złym świetle; 2) przez unikanie możliwych skojarzeń kultu prawdziwego Boga z symboliką misteryjną.
\end{abstract}

Słowa kluczowe: Septuaginta, kulty misteryjne, mirt, bocian, dudek, $\mathrm{Hi}$ 17,6, Hi 31,5, Oz 4,12, Oz 10,12, Ezd 2,63, Neh 7,65, Za 1,8, Za 5,9

Abstract: The article provides an analysis concerning the occurrence of some mysteric terms present in the translation of the Septuagint. Greek mystery cults were widely popular at the time when the translation was made. Some parts of the cult were kept undercover. However, the vocabulary, some of the symbols or ideas were widely known to the people, including the Jewish community living in the diaspora of Alexandria. No wonder one can find the words linked to the mystery cults in the Septuagint. What calls one to consider the theme is that some Greek terms linked to the mystery cults in LXX translated the original Hebrew text improperly and thus changed its meaning. Such a situation occurs, e.g., in the book of Hosea where the words light and knowledge appear, whereas the Hebrew text speaks about agriculture, and in the book of Zecharia where the Hebrew word myrtle is translated to mountain and stork to hoopoe. The article provides an analysis of the work of the translators of LXX and the motives of their actions. What can be seen is the polemic with the mysteric cults that is conducted in two ways: firstly, by presenting the mysteric cults and their participants in a negative light; secondly, by avoiding any possible positive associations of the faith of God of Israel with the mystery symbolism.

Keywords: Septuagint, mysteric cults, myrtle, stork, hoopoe, Job 17:6, Job 31:5, Hos 4:12, Hos 10:12, Ezr 2:63, Neh 7:65, Zech 1:8, Zech 5:9 
Religijny fenomen misteriów, ich kultów i wtajemniczeń był znany i obecny w życiu Greków od czasów archaicznych. Już od VI w. przed Chr. obchodzone były święta i wtajemniczenia w najstarszym i najbardziej znanym ośrodku misteryjnym, w Eleusis. Były to misteria związane z postacią bogini Demeter. Jak opowiada to homerycki Hymn do Demeter, bogini, która w tym właśnie miejscu znalazła pocieszenie po stracie córki Persefony z wdzięczności nauczyła ludzi, jak osiągnąć szczęśliwe życie po śmierci. Zapewnienie osiągnięcia tego celu odbywało się przez przejście rytuału odpowiedniego wtajemniczenia ${ }^{1}$. Misteria eleuzyńskie nie są jedynymi, jakie znali Grecy, równie starożytne są misteria orfickie, związane z Dionizosem. Początkowo misteria pozostawały na uboczu w relacji do oficjalnej religii greckiej, w której centrum pozostawał panteon bogów olimpijskich. Jednak w czasach helleńskich, kiedy to po podbojach Aleksandra Wielkiego mocno osłabła instytucja polis i w związku z tym także religia grecka zmieniła swój charakter z oficjalnego, wspólnego dla wszystkich, na bardziej indywidualny, misteria zyskiwały coraz większą popularność. Rozprzestrzeniały się one na cały świat helleński i przybierały nowe formy poprzez łączenie ich treści z bóstwami innych religii. Tak pojawiły się nowe formy misteriów dionizyjskich bądź bakchicznych, misteria Matki Ziemi (Wielkiej Macierzy), misteria Kabirów czy misteria perskiego boga Mitry. W końcu, przede wszystkim przez osobę Tymoteusza Eumolpidy, dotarły do ptolemejskiego Egiptu, gdzie zostały połączone z osobami Izydy oraz Ozyrysa ${ }^{2}$. Misteria wpływały na różne obszary życia ludzkiego, nie ograniczały się tylko do obrzędów, ale przekładały się na światopogląd i sposób życia wtajemniczanych oraz tych, którzy stykali się z ich doktryną i w jakiś sposób poddawali się ich wpływowi. Wśród wtajemniczonych znajdowały się osoby ze wszystkich warstw społecznych, zarówno niewolnicy, jak i filozofowie (np. Epikur) czy rzymscy cesarze (np. August czy Hadrian) $)^{3}$.

Choć przebieg i dokładna treść misteriów były mocno strzeżoną tajemnicą, za której ujawnienie groziła śmierć, to jednak wiele ich elementów było znanych powszechnie. Świadczy o tym choćby parodia kosmogonii orfickiej, jaką zamieścił Arystofanes w swojej komedii Ptaki ${ }^{4}$. Poczynione przez poetę aluzje z pewnością nie były przeznaczone jedynie dla wtajemniczonych w te misteria, ale miały być rozumiane przez całą publiczność zgromadzoną w teatrze i oglądającą sztukę. Również i inne znane nam nawiązania, np. u Platona, u Chryzypa, u Cycerona czy też w Żabach Arystofanesa, pokazują, że pisma i doktryny orfików oraz pewne elementy misteriów eleuzyńskich czy innych, były znane, a może nawet dobrze znane w społeczeństwie

1 Schneider, Rzut oka, 5; Banek, „Misteryjne kulty”, 77; Kolankiewicz, „Eleusis”, 32; Nowaszczuk, „W kręgu religijności antycznej", 177.

2 Świderkówna, Bogowie zeszli z Olimpu, 48-49, 147, 250; Świercz, Jedność wielości, 68; Trzcionkowski Wójtowicz, „Misteria”, 1263; Sfameni, Misteri e teologie, 53-87.

3 Świderkówna, Bogowie zeszli z Olimpu, 85; Homa, „Misteria eleuzyńskie”, 115; Nowaszczuk, „W kręgu religijności antycznej", 198.

4 Aristophanes, Aves 927-930. 
Aten czy innych miast greckich. Jednocześnie kultom misteryjnym towarzyszyły, $\mathrm{w}$ większości przypadków, formy religijne przeznaczone dla niewtajemniczonych ${ }^{5}$.

Misteria - $\mathrm{w}$ różnej formie - były zatem znane i popularne w całym świecie hellenistycznym. Jako takie nie były z pewnością obce również Izraelitom, zwłaszcza tym żyjącym w diasporze. Co oczywiste, dla prawowiernych Izraelitów misteria były jednym z przejawów pogańskiego bałwochwalstwa. Uznawali je zapewne za szczególnie niebezpieczne i przewrotne, ponieważ zawierały w sobie element epifanii bóstwa pogańskiego, która miała prowadzić do przemiany człowieka (przebóstwienia) i w ten sposób dawać wtajemniczonym nie tylko odmianę życia na ziemi, ale także (i to przede wszystkim) pewność szczęśliwego życia pośmiertnego. Misteria polegały na oddaniu się bóstwu pogańskiemu, a ich celem było budowanie swej przyszłości (ziemskiej i wiecznej) właśnie na tej podstawie. Od razu staje się więc widoczne, że było to nie do pogodzenia $\mathrm{z}$ wiarą $\mathrm{w}$ Jedynego prawdziwego Boga, który objawił się Izraelowi. Prowadziło to do nieuchronnej konfrontacji, zwłaszcza w diasporze, gdzie Izraelici często, wręcz nieustannie, natrafiali na obecność religii misteryjnych. Tak było i w Aleksandrii, z jej misteryjnym Serapejonem z jednej strony i z dużą wspólnotą żydowską $z$ drugiej. Ślady tej konfrontacji widzimy między innymi na kartach Starego Testamentu, a dokładnie w jego tekście greckim, zarówno w księgach deuterokanonicznych, jak i w tłumaczeniu Septuaginty, która - jak zauważa Anna Świderkówna „unikała nader starannie wszystkiego, co miało jakiś związek z pogańską mitologią”.

Choć przebieg i treść misteriów były tajemnicą (były one zarówno ״’ $\rho \rho \eta \tau \alpha-$ „niewypowiadalne”, „niemożliwe do opowiedzenia”, jak i $\alpha$ mó $\rho \rho \tau \alpha$ - „zakazane do opowiadania"), to słownictwo związane z misteriami było znane i wręcz weszło do języka codziennego Greków oraz zhellenizowanych narodów. Pomimo tego, że często słowa te były używane w sposób neutralny, nie w swoim pierwotnym, technicznym znaczeniu, to cały czas pobrzmiewało $\mathrm{w}$ nich ich misteryjne tło oraz pochodzenie, którego nie dało się wymazać (np. „bluszcz” jako ich symbol; podobnie jak dziś „choinka” i jej związek ze świętami Bożego Narodzenia). Celem niniejszego opracowania jest zbadanie i podanie przykładów polemiki świata żydowskiego ze światem misteriów obecnych w tekście Septuaginty. W tłumaczeniu tym znajdujemy miejsca, które oddają tekst hebrajski w sposób zaskakujący, zmieniając jego wymowę, a nawet jego sens. Użyte w takich miejscach słownictwo, związane ze światem misteriów i ich obrzędów, mocno przemawia za celowością takiego zabiegu. To z kolei każe postawić problem: na ile taka zmiana ma charakter polemiczny? oraz czy da się ją wytłumaczyć w inny sposób? W naszej pracy nie będziemy się odnosić do najbardziej znanych i oczywistych słów związanych z misteriami, tj. $\mu \nu \sigma \tau \eta \dot{\rho} \rho\llcorner\nu \nu, \tau \in \lambda \in \tau \eta \dot{\eta}, \epsilon \pi o ́ \pi \tau \eta \varsigma$

5 Harvey, „The Use of the Mistery Language”, 320, 322, 331; Świderkówna, Bogowie zeszli z Olimpu, 90, 214, 367; Lengauer, „Hieroi logoi”, 24; Świercz, Jedność wielości, 68, 83; Sfameni, Misteri e teologie, 87; Burkert, Starożytne kulty misteryjne, 50-51.

6 Świderkówna, Bogowie zeszli z Olimpu, 282, 336; por. Wojciechowski, Wplywy greckie, 27-31; Laskowski, „Niektóre aspekty”, 332-333. 
czy $\theta^{\prime} \alpha \sigma o \varsigma$ - uczynił to już swej pracy Łukasz Laskowski ${ }^{7}$ - a skupimy się na kilku słowach rzadziej używanych, „drugorzędnych”.

\section{Słowo $\gamma \varepsilon \dot{\lambda} \omega \varsigma$ w przekładzie Hi 31,5 oraz 17,6}

Zaczniemy od słowa $\gamma \varepsilon \dot{\varepsilon} \omega \omega$, na które swoją uwagę zwrócił Laskowski. Zauważa on, że rzeczownik $\gamma \varepsilon \dot{\varepsilon} \lambda \omega \varsigma$ może nawiązywać do misteriów Dionizosa, ponieważ wtajemniczenie w nie wiązało się ze śmiechem jako znakiem dobroczynnego działania bóstwa, a jego personifikacja znana była pod imieniem $\Gamma \dot{\lambda} \lambda \omega \varsigma$ (Śmiech). Ponadto, jak zaświadcza Atenajos, na dworze Ptolemeusza IV Filopatora (zm. 204 r. przed Chr.) uczestnicy uczt powiązanych z kultem tego boga byli nazywani $\gamma \varepsilon \lambda$ oı $a \sigma \alpha i^{8}$.

To właśnie słowo spotykamy w greckim tłumaczeniu Księgi Hioba, w wersecie 31,5, choć tekst hebrajski tego wersetu nie zawiera żadnej treści kojarzącej się ze śmiechem. Analizowane zdanie jest częścią mowy Hioba, w której uzasadniając swoją niewinność i bezgrzeszność, odrzuca jeden po drugim grzechy, które można popełnić i w ten sposób obrazić Boga. W wersecie 31,5 Hiob wymienia grzechy bałwochwalstwa oraz zdrady i podkreśla swą niewinność mówiąc:

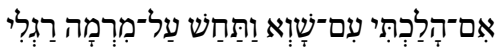

„Jeżeli chodziłem z bożkiem i spieszyła do oszustwa moja noga”.

Tłumaczenie tego zdania w Septuagincie brzmi następująco:

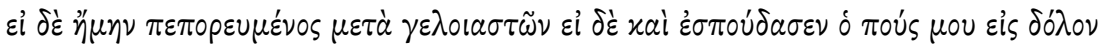
„Jeżeli chodziłem ze śmieszkami i jeżeli spieszyła moja noga do oszustwa”.

W zdaniu tym hebrajskie słowo שְָׁ zostało przetłumaczone przez greckie

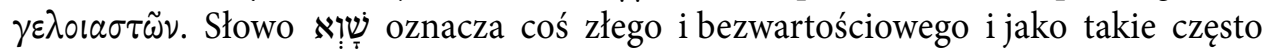
w ST jest stosowane na określenie figur czy posągów obcych bóstw9 ${ }^{9}$. Greckie słowo $\gamma \varepsilon \lambda$ ol $\sigma \tau$ '่s, które mu odpowiada w tłumaczeniu LXX, oznacza dosłownie „śmieszek”, „błazen”"10, co już samo w sobie może zawierać element dyskredytacji obcych bogów i ich posągów. Jednak Septuaginta zazwyczaj tłumaczy słowo שָ innymi słowami, bardziej odnoszącymi się wprost do braku wartości czy pustoty (najczęściej

Laskowski, „Niektóre aspekty”, 331-354.

8 Laskowski, „Niektóre aspekty”, 341-342; por. Rengstorf, „ $\gamma \varepsilon \lambda \alpha^{\alpha} \omega$ ”, 660-661; Paganini, „Greek and Egyptian Associations", 137.

9 HALOT II, 428-429.

10 Abramowiczówna, Stownik, I, 457. 


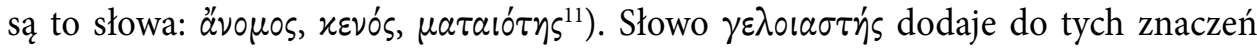
pewien rodzaj szyderstwa: bożki pogańskie to nie tylko coś pustego, ale jeszcze do tego pośmiewisko, coś co wywołuje śmiech. Ale wydaje się, że nie tylko to było celem autora greckiego przekładu Księgi Hioba. Jej tłumaczenie, które jest jednym z późniejszych w całej Septuagincie i dość swobodne, zawiera wiele nawiązań do hellenizmu $^{12}$. Z jednym z nich mamy właśnie do czynienia w przekładzie omawianego wersetu. Tłumacz, świadomie wybierając słowo, które w jego środowisku było znane jako określenie uczt związanych z Dionizosem, nie tylko wyśmiewa posągi obcych, pogańskich bogów, ale również dyskredytuje sam kult Dionizosa i jego uczestników, zestawiając jego wartość z bezwartościowymi (שָָׁ) posągami bożków. Grzech określany przez Hioba przestaje być ogólnym grzechem bałwochwalstwa, a staje się konkretnym grzechem uczestnictwa w misteryjnym kulcie Dionizosa, popularnym

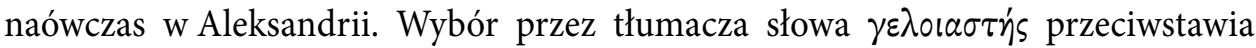
mocno kult tego greckiego boga prawdziwej wierze i czci prawdziwego Boga. Być może tłumacz nie przełożył hebrajskiego שָָׁ za pomocą jakiegoś ogólnego greckie-

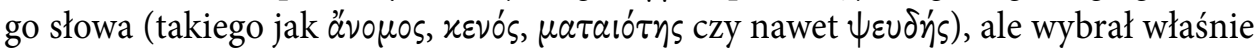
to konkretne, odnoszące się do grupy czcicieli misteriów Dionizosa, ze względu na drugą część tego wersetu 31,5. Wers ten to paralelizm synonimiczny, a jego druga część dookreśla termin bożka pogańskiego słowem מרְְמָ, które oznacza „podstęp”,

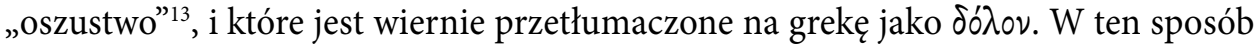
w greckim tłumaczeniu wypowiedzi Hioba uczestnictwo w ucztach dionizyjskich to nie tylko pośmiewisko, ale też postępowanie za czymś, co jest oszustwem i polega na podstępie.

Te same racje stoją prawdopodobnie za użyciem pokrewnego greckiego terminu w tłumaczeniu innego tekstu tej samej księgi, wersetu 17,6. Jest to fragment odpowiedzi Hioba na drugą mowę Elifaza. Hiob skarży się tam na swoją obecną sytuację, mówiąc m.in.:

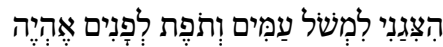

„Postawił mnie jako przysłowie dla narodów, hańbą przed nimi jestem”.

Septuaginta oddaje ten tekst następująco:

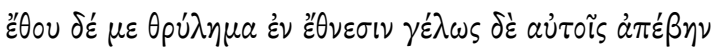

„Postawiłeś mnie jako paplaninę wśród narodów, pośmiewiskiem dla nich stałem się". 


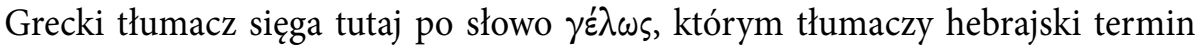
תפֶת W W tekście ST to hebrajskie słowo występuje dziewięć razy (7x w Jer, 1x w $2 \mathrm{Krl}$ i 1x w Hi), z czego osiem przypadków to określenie miejsca w dolinie Hinnom w Jerozolimie, miejsca bałwochwalczego kultu obcych bogów. We wszystkich tych miejscach słowo תפֶּ jest poprzedzone rodzajnikiem określonym. Tylko jeden raz w ST, właśnie w księdze Hioba, słowo to jest użyte bez rodzajnika, nie jako nazwa miejsca, ale w sensie ogólnym. Etymologia tego słowa wywodzi się od czasownika „wypluć”, „splunąć, a sam rzeczownik oznacza „plwocina”, a w konsekwencji także to, co jest kojarzone z pluciem i plwociną, a więc „hańba”, „upokorzenie”, „odrzucenie" ${ }^{14}$. Słowo to sprawia wiele kłopotów tłumaczom tekstu świętego. Septuaginta trzy razy nie tłumaczy go, pozostając przy transliteracji słowa hebrajskiego i zapisując je w postaci $\tau a \phi \varepsilon \theta$ ( $2 \mathrm{Krl} 23,10$; Jer 7,31.32), cztery razy oddaje je formą czasownika

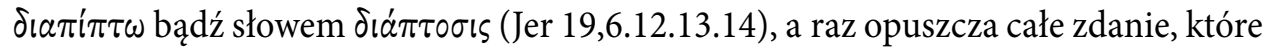
je zawiera (Jer 19,11) ${ }^{15}$. A zatem przekład terminu תפֶ słowem $\gamma \hat{\varepsilon} \lambda \omega \varsigma$, które stosuje tłumacz Księgi Hioba, nie tylko wyróżnia się, ale wręcz odcina od innych miejsc biblijnych, w których znajdujemy tłumaczenie tego hebrajskiego określenia. Grecki tłumacz miał widocznie swój cel w tym, że nie powtórzył używanych do tej pory tłumaczeń słowa תפֶּ (greckie tłumaczenie Księgi Hioba jest jednym z późniejszych), ale oddał je słowem nieużywanym gdzie indziej, a do tego nie nawiązującym ani do znaczenia czy etymologii terminu hebrajskiego, ani do miejsca noszącego tę nazwę.

W Hi 17,6 Hiob opisuje swoją obecną sytuację człowieka trędowatego i potępianego $\mathrm{z}$ tego powodu. W tym celu sięga do wyrażenia, które jak najpełniej i jak najmocniej wyrazi to, jak jest on widziany i oceniany przez innych. Takim wyrażeniem jest w świecie hebrajskim słowo תפֶֶ odnoszące się zarówno do plwociny, jak i do doliny Hinnom - miejsca popełniania grzechu bałwochwalstwa. Oczywiście w świecie greckim takie skojarzenie nie było czytelne, dlatego tłumacz LXX nie oddaje hebrajskiego terminu dosłownie ani go nie transkrybuje, ale używa greckiego słowa, które

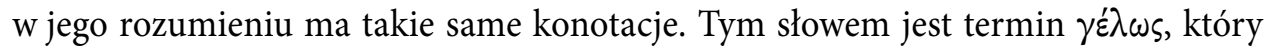
odnosi się do zgromadzeń greckiego boga i jego misteryjnego kultu. W ten sposób tłumacz łączy przynależność do zgromadzeń misteryjnych z sytuacją trędowatego Hioba, potępianego przez innych, patrzących na niego ludzi ${ }^{16}$.

14 HALOT II, 697; Driver - Gray, Commentary, 112; Tronina, Ksiega Hioba, 255.

15 Biblia Tysiąclecia oraz Biblia Poznańska oddają tekst Hi 17,6 słowem „pośmiewisko”, idąc za terminem użytym w LXX. Biblia Paulińska z kolei jest bardziej wierna tekstowi hebrajskiemu, tłumacząc to miejsce: „jestem człowiekiem, któremu pluje się w twarz".

16 Na zamierzony wybór tego greckiego słowa przez tłumacza wskazuje również fakt, że w miejscu paralelnym do omawianego zdania, w wersach Hi 30,9-10, które w dużej mierze powtarzają treść wersu 17,6, tłumacz używa greckiego słowa $\pi \tau$ $\varepsilon \lambda \lambda_{\circ}$ („ślina”, „plwocina”), które tak dobrze tłumaczyłoby również słowo z tamtego zdania. Słowo $\pi \tau \cup$ Ėos tłumaczy w Hi 30,10 hebrajskie słowo רק; sytuacja ta powtarza się również w Hi 7,19. 
Tu także efekt użycia słowa będącego równocześnie określeniem personifikacji Dionizosa wzmacnia druga część paralelizmu synonimicznego, w której hebrajskie słowo משל również nie jest przetłumaczone dosłownie, ale oddane przez greckie $\theta \rho u ́ \lambda \eta \mu \alpha$, które wywodzi się od czasownika $\theta p u ́ \lambda \varepsilon \omega$ „paplać, gadać”, a którego znaczenie można oddać jako „temat wszystkich rozmów”, czyli właśnie „paplanina”, „gadanina"17, w każdym razie coś bezwartościowego. W ten sposób kult Dionizosa zostaje skojarzony z paplaniną ludzką, i to taką, której tematem jest odrzucenie i potępienie.

\section{Słowo „symbol” w przekładzie Oz 4,12}

Kolejny przykład słowa związanego z misteriami, jakie niespodziewanie spotykamy w tłumaczeniu LXX, to $\sigma \dot{\mu} \mu \beta 0 \lambda$ ov („symbol”) w Oz 4,12. Tekst hebrajski tego wersetu zawiera oskarżenie Boga skierowane przeciw Izraelowi:

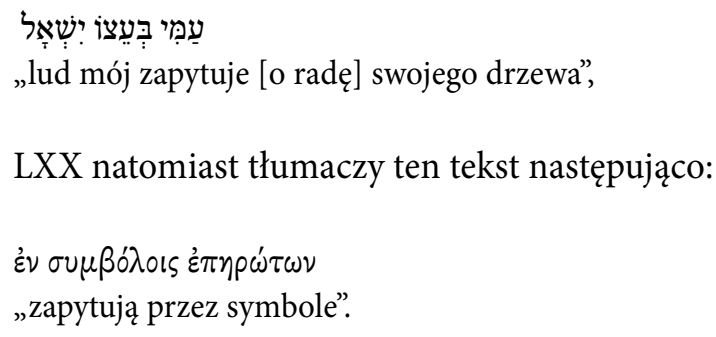

Barbara Strzałkowska notuje, że tłumacz zmienia tu formę zdania, aby uniknąć personifikacji, co jest zresztą cechą charakterystyczną całego przekładu LXX, nie tylko Księgi Ozeasza ${ }^{18}$. Można jednak zauważyć w tłumaczeniu tego wersu jeszcze jedną, bardziej znaczącą różnicę. Drewno w tekście hebrajskim odnosi się do figurki, wyobrażenia bóstwa, można je rozumieć jako laskę z wyrzeźbionym na końcu obrazem bóstwa ${ }^{19}$. Tak też rozumie je Targum Onkelosa, który oddaje je słowem צלם. Grecki tłumacz natomiast używa słowa $\sigma u ́ \mu \beta ం \lambda \circ v$, które oznacza „tajny, umówiony system znaków" i było używane jako określenie znaku zgrupowania wtajemniczonych (mistów), znaku przynależności do wtajemniczenia danego boga, znaku umożliwiającego mistom wzajemne rozpoznawanie ${ }^{20}$.

\footnotetext{
17 Abramowiczówna, Słownik, II, 473.

18 Jak zauważa sama autorka, zmiany te „są z pewnością podyktowane chęcią obrony monoteizmu przed jakimikolwiek skojarzeniami z kultami pogańskimi” (Strzałkowska, „Księga Ozeasza”, 94).

19 Por. Harper, Commentary, 259.

20 Abramowiczówna, Słownik, IV, 157; Burkert, Starożytne kulty misteryjne, 102; Trzcionkowski, „Z archeologii symbolu", 128.
} 
Pierwotnie $\sigma u ́ \mu \beta 0 \lambda o v$ był to przedmiot, który pełnił funkcję znaku rozpoznawczego, później ten sam wyraz określał także hasło, słowo służące za znak rozpoznania. $\Sigma u ́ \mu \beta ం \lambda \alpha$ były jednym z obligatoryjnych elementów rytuału inicjacyjnego, który ustanawiał między wtajemniczonymi nową relację międzyludzką, z grupy wtajemniczonych w te same misteria tworzył wspólnotę. $\Sigma u ́ \mu \beta o \lambda o v$ jako znak materialny był przepołowionym przedmiotem, który po ponownym złożeniu w całość uwierzytelniał tożsamość osób, które go posiadały. W ten sposób $\sigma u ́ \mu \beta 0 \lambda$ ov był znakiem wspólnoty tych osób, znakiem przynależności do tej samej całości. Również

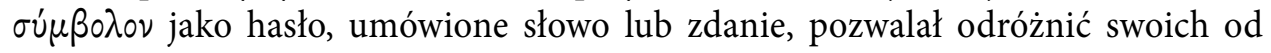
obcych. Za jego pomocą wtajemniczeni nie tylko się rozpoznawali, ale także - poszukując innych ludzi znających czy posiadających ten sam $\sigma u ́ \mu \beta 0 \lambda o v-$ dołączali do całości tworzonej przez nich. Rolę takiego $\sigma u ́ \mu \beta 0 \lambda o v$ pełniły najprawdopodobniej także tzw. ípoi $\lambda o ́$ ó, złote blaszki wkładane do grobów zmarłych, które zawierały tekst, jaki dusza powinna znać i wypowiedzieć (lub okazać) w świecie podziemnym, aby uniknąć losu zwykłych ludzi i zapewnić sobie rozpoznanie przez bogów i dopuszczenie do ich grona. Przykładem takiego przedmiotu jest blaszka z ok. 350 r. przed Chr., odkopana w pobliżu tesalskiego miasta Feraj, która jako tytuł ma wła-

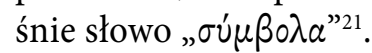

$\Sigma u ́ \mu \beta 0 \lambda o v$ nie był ani figurką, ani wyobrażeniem boga, dlatego użycie tego słowa jako tłumaczenie hebrajskiego עִ jest zaskakujące, tym bardziej że LXX tłumaczy Księgę Ozeasza wiernie, oddając zwłaszcza sens i znaczenie hebrajskiego oryginału, pomimo tego, że w kilku miejscach wprowadza intencjonalne poprawki tekstu ${ }^{22}$. Jeśli jednak zauważymy, że drewniana figurka bożka (עָץ) jest też znakiem wyznawania, oddawania czci temu bożkowi przez pewną grupę ludzi (Izraelitów), może nie znakiem rozpoznawczym, ale z pewnością elementem łączącym i wyróżniającym tę grupę, to rzeczywiście takie znaczenie bliskie jest greckiemu i misteryjnemu

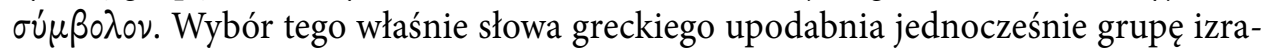
elskich bałwochwalców do jednego ze stowarzyszeń misteryjnych, a zatem utożsamia w pewien sposób bałwochwalstwo z kultem misteryjnym. Używając słowa $\sigma u ́ \mu \beta ం \lambda o v$ w tak negatywnym kontekście, w kontekście bałwochwalstwa wyraźnie potępianego przez wyrocznię proroka, tłumacz LXX przedstawia jako równie bałwochwalczy cały ruch misteryjny. Warto zauważyć, że to nie jedyny taki zabieg greckiego tłumacza Księgi Ozeasza. Podobne postępowanie możemy znaleźć w Oz 4,14 i w 9,1023 czy w wersie 7,9.

21 Por. Platon, Symposion 191d: „Każdy z nas jest symbolon człowieka [...]. I każdy stale szuka swego symbolon”. Trzcionkowski, „Z archeologii symbolu”, 114-116.

22 Strzałkowska, „Księga Ozeasza”, 89, 93-98.

23 Zob. Laskowski, „Niektóre aspekty”, 336-337, 350-351. 


\title{
3. Słowa $\varphi \omega t i \zeta \omega$ oraz $\gamma v \tilde{\omega} \sigma \iota \varsigma$ i $\tau \varepsilon \dot{\lambda} \varepsilon \varepsilon \iota \varsigma$ w przekładzie Oz 10,12 i Ezd 2,63/Neh 7,65
}

Również w Księdze Ozeasza znajdujemy kolejny przykład zaskakującego tłumaczenia tekstu hebrajskiego, połączonego $\mathrm{z}$ użyciem słownictwa misteryjnego. $\mathrm{W}$ wersie 10,12 fraza:

\author{
נִירוּ לֶָכם נִיר \\ „Czyńcie sobie nowe pola uprawne” \\ jest oddana jako: \\ $\phi \omega \tau i \sigma \alpha \tau \varepsilon \dot{\varepsilon} \alpha u \tau \sigma i \tilde{\varsigma} \phi \tilde{\omega} \varsigma \gamma \nu \omega \dot{\sigma \varepsilon \omega \varsigma}$ \\ „Zaświećcie sobie światło wiedzy”.
}

Dlaczego tłumacz LXX zupełnie zmienił tutaj treść zdania hebrajskiego? Czasownik ניר jest trudny do dokładnego oddania. Występuje on w Biblii Hebrajskiej tylko dwa razy (Oz 10,12; Jer 4,3), zawsze w parze z pokrewnym rzeczownikiem נִיר (występuje ponadto w Prz 13,23). Ponieważ rzeczownik oznacza „dziewiczą rolę, przygotowaną pierwszy raz pod uprawę”, czasownik ניר rozumiany jest jako czynność orania pola po raz pierwszy, karczowania ziemi przeznaczonej do uprawy czy tworzenia nowego pola uprawnego ${ }^{24}$. Takie znaczenie jest wyraźnie widoczne w Jer 4,3, który w kontekście rozchodzenia się błogosławieństwa Boga na pogan, metaforycznie wzywa Izraelitów: „czyńcie sobie nowe pola”, czyli nowe przestrzenie dla błogosławieństwa Boga, oraz: „nie siejcie w cierniach”, aby nie marnować tego, co jest dawane od Boga. Tak też ten tekst rozumie LXX, tłumacząc go słowami: $\nu \varepsilon \omega ́ \sigma \alpha \tau \varepsilon$

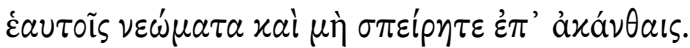

W Oz 10,12 jednak identyczne zdanie hebrajskie LXX tłumaczy zupełnie inaczej:

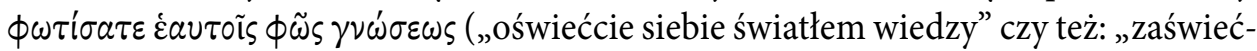
cie sobie światło wiedzy"). Zarówno $\phi \omega \tau i \zeta(\omega$, jak i $\gamma \nu \tilde{\omega} \sigma ı \varsigma$ nie są terminami technicznymi używanymi w misteriach greckich, ale należą do słownictwa związanego z misteriami i używanego $\mathrm{w}$ ich środowisku w swoistym i właściwym sobie znaczeniu ${ }^{25}$, przez co grecki przekład wydaje się wzywać do poszukiwania czy też do dążenia do jakiegoś głębszego poznania lub zrozumienia (pochodzącego od Pana, jak można zrozumieć z kolejnego wezwania: „szukajcie Pana” - tym razem wiernie tłumaczącego tekst hebrajski). Można zatem podejrzewać, że grecki tłumacz porównuje „szukanie Pana” i dążenie do poznania Boga i Jego sprawiedliwości do misteryjnego oświecenia i wtajemniczenia. Czy jednak taki zamiar usprawiedliwia aż tak dużą in-

\footnotetext{
HALOT I, 655.

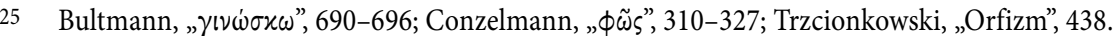


gerencję w tekst święty? Wbrew pozorom ingerencja nie jest aż tak duża i znajduje swoje wyjaśnienie.

$\mathrm{Z}$ całą pewnością tekst hebrajski $\mathrm{Oz} 10,12$ ma takie samo znaczenie jak w Jer 4,3. Przemawia za tym wyraźnie kontekst tego wiersza, w którym spotykamy słowa związane z pracą na roli: zaprzęgać, orać, bronować $(10,11)$, siać $(10,12)$, uprawiać, zbierać $(10,13)$. W 10,12 prorok wzywa: siejcie sprawiedliwość, aby zbierać miłosierdzie (חֶֶ); a żeby mieć tego plonu więcej - czyńcie sobie nowe pola (aby więcej posiać i zebrać). Dlaczego zatem LXX oddaje słowa נִיר słowami $\phi \omega \tau i \zeta \omega$ i фஸ̃ s? Słowo נִ oznacza nie tylko „nową, dziewiczą ziemię,, ale również „światło, kaganek", podobnie jak inna forma tego rzeczownika: נִ. HALOT podaje, że słowo to, w formie נִ̣, oznacza „światło, ale też „, uprawną) rolę leżącą odłogiem”26. Warto zauważyć, że pokrewny czasownik נור oznacza „dawać światło, iskrzyć się" (od niego pochodzi nazwa menora), a HALOT łączy te czasowniki z rdzeniem נהר, który odnosi się do czynności świecenia, promieniowania, także w sposób metaforyczny ${ }^{27}$. Jaki jest jednak związek tych słów z karczowaniem nowego pola uprawnego? Czasownik ניר/ związany jest ze świeceniem światła, z iskrzeniem, może zatem odnosić się do tworzenia nowego pola uprawnego poprzez wypalenie ogniem jego powierzchni, a nie do karczowania drzew czy orania po raz pierwszy. W takim razie rzeczownik נִ oznacza taką wypaloną ziemię, przeznaczoną do zaorania po raz pierwszy, aby następnie uprawiać na niej zboże ${ }^{28}$. Widzimy zatem, że analizowane słowa hebrajskie niosą w sobie również (i to mocno) znaczenie światła oraz dawania ognia i światła. Dlatego tłumacz LXX tak je odczytał i oddał słowami $\phi \omega \tau i \zeta \omega$ oraz $\phi \tilde{\omega} \varsigma$.

Nadal jednak pozostaje do wyjaśnienia problem, dlaczego Septuaginta używa tu słownictwa związanego ze światłem, skoro zupełnie nie pasuje ono do bezpośredniego kontekstu? Może ono wprawdzie łączyć się ze zdaniem następnym („Szukajcie Pana..."), ale TM tego nie usprawiedliwia. Tekst hebrajski jest bardziej naturalny, oczywisty; tłumacz LXX musiał mieć powód, aby go zmienić. Ten powód znajdujemy w hebrajskim słowie עِת („czas”, „teraz”) przetłumaczonym jako „wiedza” $(\gamma \nu \tilde{\omega} \sigma / \varsigma)$.

W tekście hebrajskim mamy tu wyrażenie וְְֵ Tג, rozpoczynające kolejne zdanie; LXX zamienia w tym wyrażeniu literę i na literę ד, odczytuje je jako słowo tuje jako słowo kończące zdanie poprzednie. Nie da się rozstrzygnąć, czy tłumacz LXX miał do czynienia z inną, nieznaną nam recenzją tekstu, czy dysponował skażonym rękopisem, czy też wprowadził koniekturę tekstu, świadomie albo w sposób

HALOT I, 679.

HALOT I, 636, 643.

HALOT (I, 713) podaje słowo pochodne od tego rdzenia, סָנְׁ, i tłumaczy je jako „oślepiać”, „Zaślepiać”. Odnosząc się do treści niesionej przez rdzeń נור oraz uwzględniając kontekst ich użycia w tekście biblijnym, można je rozumieć bardziej precyzyjnie jako: „oślepić przez wypalenie oczu (ogniem lub blaskiem)". 
niezamierzony ${ }^{29}$. W każdym razie odczytanie hebrajskiego słowa jako przetłumaczenie go jako $\gamma \nu \tilde{\omega} \sigma \iota \varsigma$ stworzyło problem: co robi takie słowo w zdaniu mówiącym o przygotowywaniu nowej roli? Aby go rozwiązać tłumacz rozczytał słowa ניר i jako odnoszące się nie do tworzenia nowego pola, ale do świecenia światła, konkretnie światła wiedzy. W ten sposób to zdanie w języku i w środowisku greckim zostaje osadzone w tle misteriów i wtajemniczeń, używając ich słownictwa oraz związanego z nimi motywu. Konsekwencją tego jest jeszcze jedna zmiana, oddanie

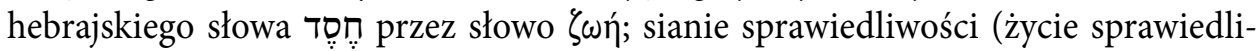
wości) ma przynieść owoc, którym jest życie (a nie miłosierdzie Boga). Taka zmiana sprawia, że w zdaniu tym pobrzmiewa etyka oraz światopogląd orficki: aby zdobyć owoc życia (lub: owoc, którym jest życie - genentivus epexegeticus), należy zaświecić sobie światło wiedzy ${ }^{30}$.

Greckie tłumaczenie $\mathrm{Oz}$ 10,12 zawiera słownictwo misteryjne i nawiązuje do takich motywów, co jest zaskakujące, gdyż sens tekstu hebrajskiego jest tu wyraźnie zmieniony. Jednak w tym wypadku nie wydaje się, aby intencją tłumacza była polemika czy chęć zdeprecjonowania kultów misteryjnych, raczej korzysta on ze słownictwa związanego z misteriami, ale używanego także poza nimi.

Słowo $\phi \omega \tau i \zeta \omega$, i to w połączeniu ze słowem $\tau \dot{\varepsilon} \lambda \varepsilon ı$ เos, pojawia się także niespodzie-

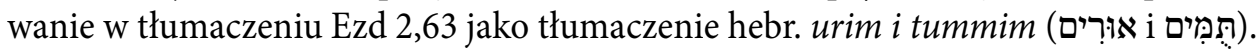
Tekst ten przedstawia decyzję namiestnika, która zakazuje kapłanom niepotrafiącym dowieść swego kapłańskiego rodowodu spożywania ze świętych pokarmów, „aż zjawi się kapłan dla urim i tummim" i ewentualnie przedstawi wyrocznię Bożą co do autentyczności ich kapłaństwa. Interesujący nas tekst hebrajski, który brzmi:

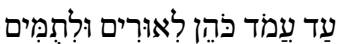

„aż nastanie kapłan dla urim i dla tummim”,

przełożony jest jako:

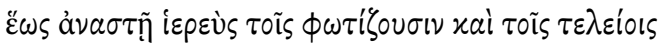

„aż nastanie kapłan dla oświeconych i dla doskonałych”.

Przyglądając się temu zaskakującemu tłumaczeniu, zauważamy najpierw, że urim i tummim, zarówno wtedy, gdy występują razem, jak i wtedy, gdy jest użyte jedno

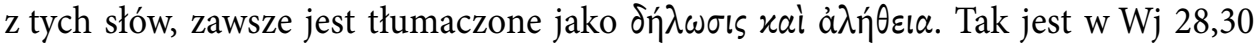
Kpł 8,8, Lb 27,21, Pwt 33,8, 1 Sm 28,6. Te właśnie słowa są użyte także w greckim

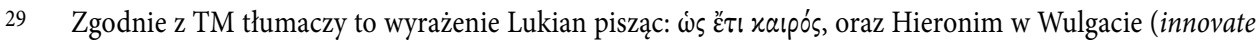
vobis novale tempus autem requirendi Dominum).

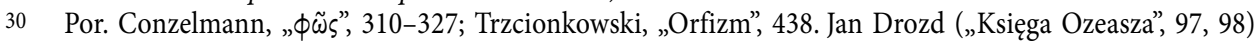
w swoim komentarzu próbuje połączyć i ujednolicić te dwa sposoby odczytania tego zdania i tłumaczy je następująco: „użyźniajcie (uprawiajcie) sobie rolę wiedzy”. 
tekście Syr 28,6 i 45,1, a tylko w tym jednym tekście Księgi Ezdrasza wyrażenie to oddane jest zupełnie inaczej. $Z$ drugiej strony nie możemy nie zauważyć, że tłumaczenie Księgi Ezdrasza jest dosłownym tłumaczeniem nazwy hebrajskiej; tummim wywodzi się od słowa תָּ i oznacza „doskonałość”, „nieskazitelność”, czyli $\tau \varepsilon \dot{\lambda} \lambda \varepsilon ı \varsigma$, natomiast urim odnosi się do światła czy też blasku (אiא), co odpowiada greckiemu $\phi \omega \tau i \zeta \omega$. Greckie tłumaczenie jest na tyle dosłowne, że oddaje nawet liczbę mnogą, jaką możemy odczytać z końcówek słów hebrajskich. Dodatkowo można zauważyć, że tylko w tym miejscu słowa urim i tummim są użyte bez rodzajnika ${ }^{31}$. To dosłowne oddanie nazwy hebrajskiej zmienia sens całego zdania: oczekiwany kapłan nie jest już kapłanem, który daje wyrocznię za pomocą urim i tummim, ale staje się kapłanem w odniesieniu do światłych (oświeconych) oraz doskonałych (wtajemniczonych). To w oczywisty sposób kojarzy go z uczestnikami kultów misteryjnych. Nie wydaje się jednak, aby właśnie takie skojarzenie było celem autora przekładu. Użyte przez niego słowa oraz ich forma wydają się raczej być wynikiem nieznajomości wyroczni urim i tummim i sposobu jej używania. Stąd przekład dosłowny, niemal literalny, tekstu hebrajskiego ${ }^{32}$. Samo natomiast skojarzenie $\mathrm{z}$ misteriami nie jest celowe, ale raczej mimowolne i niezamierzone, trudno bowiem posądzić autora o chęć połączenia z nimi świętego narzędzia wyroczni Bożej czy też kapłana mającego przynieść od Boga rozstrzygnięcie problemu.

Celowe i zamierzone działanie możemy natomiast zauważyć w tłumaczeniu tego samego tekstu znajdującego się w Księdze Nehemiasza. Wymowa greckiego tekstu Ezd 2,63 oraz wywoływane przez niego skojarzenia z misteriami zostały uznane za niewłaściwe przez jej tłumacza. Tłumacząc tekst Neh 7,65, który w Biblii Hebrajskiej jest literalnym powtórzeniem Ezd 2,63, nie kopiuje on dokonanego już tłuma-

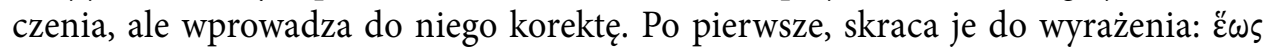

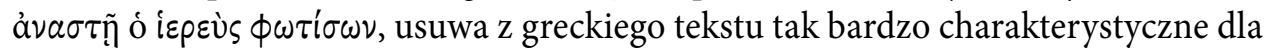

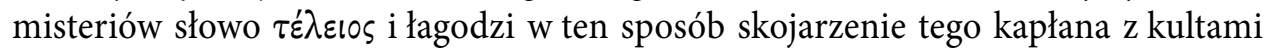
obcymi. Po drugie, zmienia formę słowa $\phi \omega \tau \tau^{i} \zeta \omega \mathrm{z}$ dativu part. praes. na nominativus part. fut.; kapłan, którego oczekują Izraelici, przestaje być zatem „kapłanem dla światłych”, staje się natomiast „kapłanem, który przyniesie światło”. Choć dalej nie oddaje to sensu tekstu hebrajskiego, to unika skojarzeń z bałwochwalczymi misteriami. Ta korekta przekładu wskazuje, że tłumacz Księgi Nehemiasza celowo chce uniknąć jakichkolwiek skojarzeń oczekiwanego kapłana Boga ze środowiskiem misteriów greckich.

31 Batten, Commentary, 97.

32 Z podobną sytuacją mamy do czynienia w 1 Krl 15,12, gdzie słowo קְדְשׁים którego właściwe znaczenie było już zapomniane i nieznane, zostaje oddane przez aktualnie używane $\tau \dot{\alpha} \varsigma \tau \varepsilon \lambda \varepsilon \tau \dot{\alpha} \varsigma$. Por. Laskowski, „Niektóre aspekty”, 348-349. 


\section{Usunięcie słowa „mirt” w tłumaczeniu Księgi Zachariasza}

Inny przykład polemiki z kultami misteryjnymi możemy znaleźć w Księdze Zachariasza. Jest on o tyle interesujący, że znajdujemy tam polemikę prowadzoną w sposób odmienny od tego, jaki przedstawiały przykłady podane do tej pory. Polemika przedstawiona w Księdze Zachariasza nie jest prowadzona przez używanie słownictwa misteryjnego w negatywnym zabarwieniu, ale przez unikanie słowa kojarzonego z misteriami, które musiałoby się pojawić w znaczeniu pozytywnym. Słowem tym jest słowo „mirt”, które tłumacz omija, zmieniając zdanie mówiące o pojawieniu się jeźdźca „między dwoma mirtami” na tekst mówiący o jego pojawieniu się „między dwoma górami".

Słowo „mirt” (הְדְ) pojawia się w ST sześć razy. Trzy razy (Iz 41,19; 55,13; Neh 8,15; zawsze poza Księgą Zachariasza) tłumaczone jest dosłownie przez greckie $\mu$ u $\sigma i$ in , a trzy razy, zawsze w księdze Zachariasza $(1,8.10 .11)$, jest oddane przez greckie öpos („góra”). Wszystkie miejsca występowania tego słowa w Księdze Zachariasza należą do opisu pierwszej wizji proroka. Przedstawia ona jeźdźca siedzącego na kasztanowatym koniu, który znajduje się „między dwoma mirtami w dolinie” $(1,8)$. Wers 11 podaje, że między tymi samymi drzewami mirtowymi stoi „anioł Pański”. Niezależnie od tego, czy należy te dwie postaci utożsamić, czy też potraktować je jako dwie osoby, jedno jest pewne - i jeździec, i anioł są posłani przez Boga i spełniają Jego misję.

W tekście hebrajskim ST mirt pojawia się zawsze w pozytywnym wymiarze. Dwa proroctwa Księgi Izajasza wymieniają mirt wśród szlachetnych drzew, którymi Bóg zalesi pustynię $(41,19)$ i które zastąpią przeciwstawione im nieużyteczne i szkodliwe rośliny, ciernie i pokrzywy $(55,13)$. Mirt jest zatem rośliną, która przypomina Izraelitom o Bożej dobroci, w przeciwieństwie do cierni i pokrzyw. Z gałęzi mirtu budowano szałasy w święto Namiotów (Neh 8,15; por. Kpł 23,40). Nazwa „mirt” w swej żeńskiej formie pojawia się także w imieniu Hadassy (Estery), pozytywnej bohaterki Księgi Estery. Również w wizji z Księgi Zachariasza pojawienie się wysłannika Bożego „wśród mirtów” wyraża pozytywny charakter tego proroctwa ${ }^{33}$.

Tłumacz Księgi Zachariasza konsekwentnie zmienia jednak „mirty” z tekstu hebrajskiego na "góry” w tekście greckim. Wiąże się to z koniekturą tekstu spółgłoskowego, słowo הרסים zostaje poprawione na הדים, i jest to koniektura dokonana przez tego właśnie tłumacza. W tekście oryginalnym chodzi bowiem z pewnością o mirt; tak je rozumie także Targum Onkelosa, który w tym miejscu uściśla wręcz, że jeź-

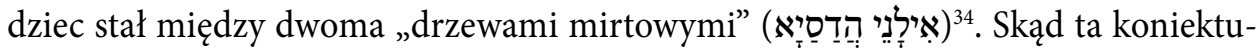

33 Lurker, Słownik obrazów, 124-125; Packer - Tenney, Słownik tła Biblii, 205; Brzegowy, Ksiega Izajasza, 592.

34 Ta zmiana dokonana w tłumaczeniu pociągnęła za sobą konieczność kolejnej koniektury. Mirty bowiem

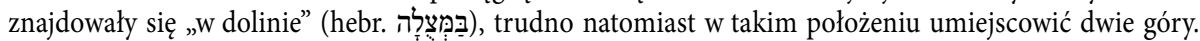

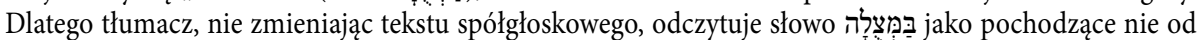

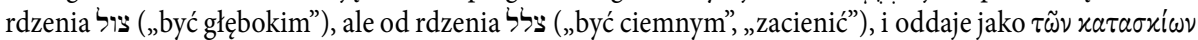


ra? Wielu egzegetów twierdzi, że tekst hebrajski uległ skażeniu oraz że tłumacz chciał uzgodnić ten szczegół pierwszej wizji z wizją ósmą (6,1-8), gdzie mowa jest o dwóch górach miedzianych. Zatem scena wizji pierwszej byłaby podobna do sceny z wizji ostatniej: anioł Jahwe stał na krańcach świata między górami położonymi od strony zachodniej, tam gdzie chowa się tarcza słoneczna ${ }^{35}$. To tłumaczenie nie brzmi jednak przekonująco, zważywszy, że targum odczytuje tekst hebrajski w formie pierwotnej i nieskażonej. Bardziej prawdopodobne jest wytłumaczenie, że autor przekładu chciał uniknąć pozytywnego skojarzenia z obrzędami misteryjnymi.

Mirt był w starożytnej Grecji uznawany za roślinę Afrodyty, ale przede wszystkim był on stosowany w kultach chtonicznych, do których należały misteria. Mirt należał do ważnych elementów misteriów eleuzyńskich, ponieważ był on rośliną Demeter i Persefony. Jego zastosowanie nie odnosiło się zresztą tylko do bogiń, wieńce mirtowe nosili zarówno ci wprowadzani w pierwsze wtajemniczenia (mistowie), jak i wtajemniczający, jak to jest widoczne w scenach inicjacji przedstawianych na wazach. Mówi o tym także opis historii wtajemniczenia Heraklesa w te misteria ${ }^{36}$, przekazany nam przez Jana Tzetzesa w Scholionie do Aleksandry Likofrona, który

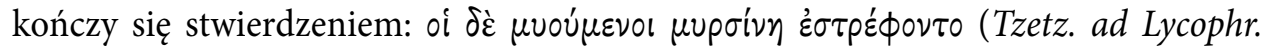
1328). Również w trakcie misteriów dionizyjskich miało miejsce nakładanie wieńców mirtowych na głowy wtajemniczanych. Poświadcza to Klemens Aleksandryjski w Pedagogu: „Wtajemniczani w misteria dionizyjskie nie odbywają obrzędów bez wieńców, ilekroć zakładają kwiaty, we wtajemniczeniu są oświecani”, oraz Harpokration z Aleksandrii w swoim Leksykonie dziesięciu mówców Attyki: „Wtajemniczani $\mathrm{w}$ misteria dionizyjskie na biało, białym mirtem, są zwieńczeni, podziemna to bowiem roślina, tak jak podziemny jest Dionizos syn Persefony" ${ }^{37}$.

Stojąc między dwoma drzewami mirtowymi, jeździec z wizji Zachariasza jest okolony gałęziami tego drzewa, niemal tak jak wtajemniczani w misteria. Aby uniknąć tego podobieństwa tłumacz nieznacznie koryguje słowo hebrajskie i oddaje je jako „góry”; w ten sposób unika skojarzenia posłańca Bożego nie tylko z wtajemniczanymi w misteria, ale również, i to może jeszcze bardziej, z wtajemniczającymi w te obrzędy. Widząc w tej wizji otoczonego czy też zwieńczonego gałęziami mirtowymi posłańca Bożego, odbierającego raport od innych posłańców (jeźdźców), można go łatwo skojarzyć z mistagogami przyjmującymi wtajemniczanych i wprowadzających ich w tajemne sprawy. Aby uniemożliwić jakiekolwiek takie

(„cieniste”), odnosząc to określenie do cechy gór, a nie do ich położenia. Por. Homerski, „Księga Zachariasza”, 314.

35 Homerski, „Księga Zachariasza”, 315; por. Mitchell - Smith - Bewer, Commentary, 119.

36 Herakles był pierwszym cudzoziemcem wtajemniczonym w misteria eleuzyńskie; inicjacja ta była warunkiem wejścia do krainy zmarłych, co było związane z jedną z dziesięciu prac, jakie miał wykonać. Kolankiewicz, „Eleusis”, 34, 55.

37 de Sousa, „O mirto em Eleusis”, 294-297; Kolankiewicz, „Eleusis”, 54; Trzcionkowski - Wójtowicz, „Misteria”, 1263; Zarewicz, „Muzaios, Orfeusz”, 383. 
skojarzenie tłumacz LXX koryguje to słowo i usuwa w ten sposób z wizji nazwę rośliny tak bardzo kojarzącej się z wtajemniczeniami greckimi. W ten sposób uzgadnia też wizję pierwszą z wizją ostatnią, która mówi o rydwanach stojących między dwoma górami.

\section{Zamiana bociana na dudka w tłumaczeniu Za 5,9}

Ten sam tłumacz Księgi Zachariasza czyni inny zabieg, który też może mieć przyczynę w skojarzeniu ze słownictwem stosowanym w misteriach. W wersecie 5,9 tłuma-

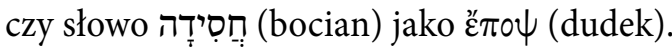

חִ Tִ je jeden z nieczystych ptaków wymienionych jako zakazane do jedzenia w Kpł 11,19i w Pwt 14,18. Dokładne rozpoznanie tych ptaków, ustalenie, jaki dokładnie gatunek kryje się za podawanymi nazwami hebrajskimi, nie jest łatwe. Tak też jest i w tym przypadku. Jedyną pewną rzecz, którą możemy powiedzieć o tym gatunku ptaka jest to, że miał on wielkie skrzydła. Stąd przez określenie zumiemy bociana lub czaplę, które odpowiadają tej charakterystyce. Tę niepewność co do identyfikacji gatunku, z uwzględnieniem jednak jego cechy szczególnej, czyli rozłożystych skrzydeł, odbijają próby tłumaczenia tego słowa w LXX. W Kpł 11,19

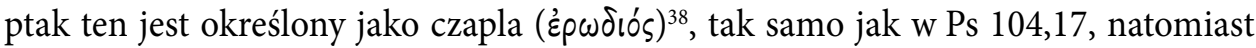
Pwt 14,18 widzi tu pelikana ( $\pi \varepsilon \lambda \varepsilon x a ́ v)$. Jer 8,7 oraz Hi 39,13 nie tłumaczą tej nazwy, pozostając przy transliteracji terminu hebrajskiego $(\alpha \sigma i \delta \alpha)$, w tym drugim przypadku, być może ze względu na to, że kontekst wskazuje, że chodzi tam o strusia. Natomiast w Za 5,9 termin hebrajski oddany jest jako dudek (žmo $\psi$ ). Jest to o tyle zaskakujące, że dudek, choć również jest ptakiem nieczystym, z całą pewnością nie

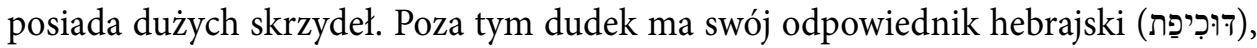
wymieniony obok חִִ̣ na liście ptaków zakazanych i przełożony przez LXX jako

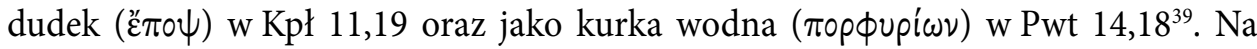
fakt, że LXX używa w swoim tekście niewłaściwego słowa wskazują inne tłumaczenia

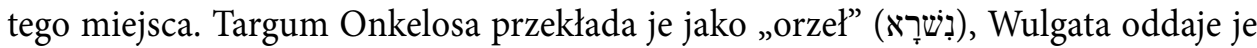
jako milvus (kania czy też ogólnie: jastrząb), również przekłady Aquili, Symmacha

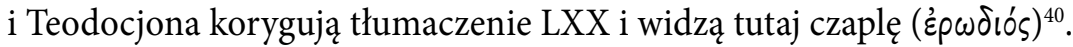

38 W tekście LXX jako pierwsza nazwa pojawia się tu wprawdzie $\gamma \lambda$ av́ („sowa”) i pozornie to ona tłumaczy hebrajskie חִסִידָה, które także znajduje się na czele wymienionych w tym wersecie gatunków. Jednak tekst grecki wymienia o jeden gatunek ptaków więcej, i to właśnie sowa nie ma odpowiednika w tekście hebrajskim, dlatego hebrajskie חִ oְ oddane jest przez znajdującą się na drugim miejscu czaplę, tak jak pozostałe nazwy greckie odpowiadają kolejnym wymienionym w tekście hebrajskim gatunkom ptaków. Por. Altmann, Banned Birds, 118-119, 122-123; HALOT I, 320. 
Za 5,9 należy do siódmej z wizji proroka, przedstawionych w księdze (Za 5,5-11). Jej treścią jest dzban o pojemności efy $\mathrm{z}$ siedzącą $\mathrm{w}$ środku kobietą, która zostaje określona jako bezbożność ${ }^{41}$. Dzban ten, wraz z zawartością, zostaje przeniesiony do kraju Szinear i tam pozostawiony. Szinear to miejsce budowy wieży Babel (Rdz 11,1-9), a więc kraj bezbożności i symbol świata pogańskiego. Cała wizja przedstawia usunięcie bezbożności z Izraela przez wydalenie jej do kraju grzechu. Wykonawcami tej czynności są w wizji dwie kobiety mające skrzydła „niby skrzydła bociana/czapli”, a więc rozłożyste, zdolne przenieść tak duży ładunek jak dzban z siedzącą w środku kobietą.

Dlaczego LXX porównuje skrzydła tych kobiet do skrzydeł dudka, który jest małym ptakiem i rozmiar jego skrzydeł kłóci się wręcz z obrazem płynącym z wizji? Wskazówką może być tutaj grecka nazwa oraz symbolika tego ptaka. W grece sta-

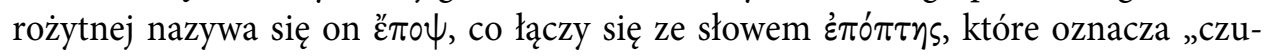
wający, opiekun, widz”, a także jest określeniem osoby wtajemniczonej w najwyższy stopień misteriów eleuzyńskich. Dlatego zapewne w wielu mitach dudek przenosi uroczyste informacje magom i wieszczkom, ponieważ niektóre ludy wierzyły, że ten ptak symbolizuje wiedzę tajemną i sekretną. Znaczące jest to, że Arystofanes właśnie dudka czyni w swojej komedii Ptaki królem ptaków, a jeszcze bardziej symboliczne

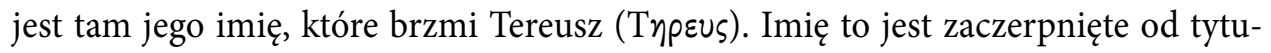

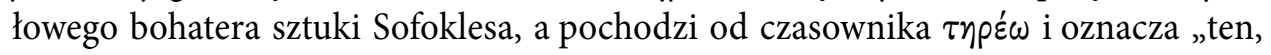
kto widzi wszystko" ${ }^{2}$. Odpowiada to znaczeniu słów है $\pi \circ \psi$ i દ̇ $\pi$ ó $\pi \tau \eta$ s, które pochodzą od czasownika દ̇фopá $\omega$, a który oznacza „patrzeć”, „widzieć”, „doglądać”, „opiekować

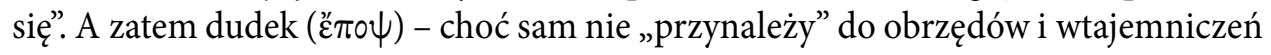
misteryjnych ani nie jest z nimi bezpośrednio związany - swą nazwą i symboliką kierował uwagę na rzeczy sekretne i tajemne (a takimi były misteria) jako ten, który widzi wszystko i „współpracuje” z wieszczkami. Sama jego nazwa wprost łączyła się $\mathrm{z}$ wtajemniczonymi w misteria, i to $\mathrm{z}$ tymi wtajemniczonymi w stopniu najwyższym. Dudek jest więc ptakiem, który bardzo wyraźnie kojarzy się z misteriami. Jest to tym bardziej warte uwagi, że zwierzęta określone w Kpł 11 i Pwt 14 jako nieczyste, $\mathrm{w}$ większości są związane z kultami obcymi lub działaniami magicznymi ${ }^{43}$.

W wizji Zachariasza kobiety ze skrzydłami wynoszą bezbożność na jej miejsce, do kraju grzechu. Właściwe zatem jest, że i one przynależą do tej sfery, sfery grzechu i bezbożności. Być może one same są wysłane z kraju Szinear, aby zanieść do niego tę bezbożność, której ten kraj jest ojczyzną. Dlatego ich skrzydła są porównane do skrzydeł bociana, które nie tylko są rozłożyste (są i inne ptaki z rozłożystymi skrzy-

\footnotetext{
41 W greckim tłumaczeniu paralelą do tego określenia jest zmiana dokonana w 5,6. W tekście hebrajskim

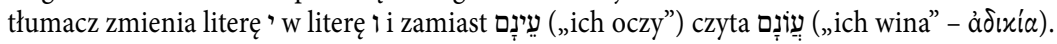

42 Por. Aristophanes, Aves 39-40, 103-104.

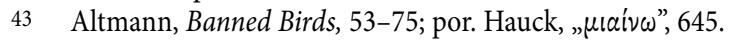


dłami, bardziej szlachetne, jak choćby orzeł ${ }^{44}$ ), ale też należą do ptaka nieczystego. Pozytywny obraz bociana w świecie greckim, gdzie był on symbolem opieki nad starymi rodzicami ${ }^{45}$, niezbyt adekwatnie łączył się ze sferą grzechu i niegodziwości z wizji prorockiej. Stąd zapewne decyzja tłumacza o zmianie gatunku ptaka na taki, który kojarzy się z rzeczami tajemnymi. Ponadto jego nazwa wprost kieruje uwagę czytelnika na wtajemniczonych w misteria, którzy dlatego właśnie są tutaj utożsamieni i powiązani z kobietami, które niosą bezbożność do kraju grzechu. A zatem wtajemniczeni, jak i same misteria powiązani zostają z grzechem i bezbożnością. Zaniedbując zatem fakt, że skrzydła dudka są za małe i nie pasują do obrazu wizji, tłumacz LXX osiągnął inny efekt: przedstawił misteria i ich obrzędy jako coś, co łączy się z grzechem, bezbożnością i nieprawością.

\section{Zakończenie}

Na koniec można zauważyć, że w LXX spotykamy także słowa używane przez uczestników kultów misteryjnych, które są typowe nie tylko dla tych środowisk, ale także używane ogólnie przez Greków i stanowiące część ich języka religijnego. Takim

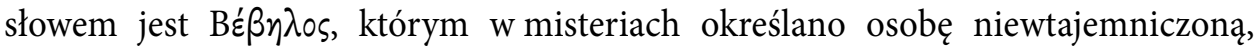

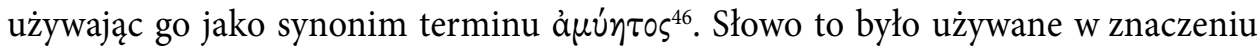
"znajdujący się przed progiem miejsca świętego" i stąd "dostępny dla wszystkich, nie poświęcony bóstwu”, a więc również „niepoświęcony”, „należący do sfery profanum" ${ }^{47}$. W LXX jest ono używane kilkakrotnie w tym właśnie znaczeniu, tłumacząc zazwyczaj czasownik חלל i jego pochodne, które określają rzeczy będące przeciwieństwem rzeczy świętych, przeznaczonych Bogu (קדָשְׁ). Tak jest np. w Kpł 21,7.9, gdzie określa on sytuacje, które bezczeszczą świętość urzędu kapłańskiego, czy w Ez 44,23, gdzie jedno z zadań kapłanów jest sformułowane jako „nauczanie ludu o różnicy

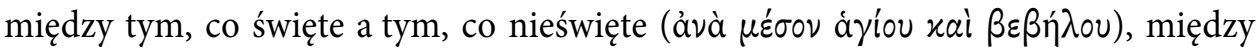
tym, co czyste a tym, co nieczyste". Równie wyraźnie jest to widoczne w 1 Sm 21,5,

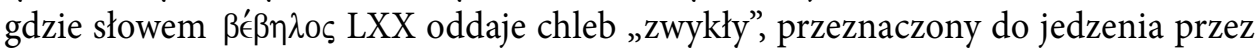
wszystkich ludzi, w odróżnieniu od chleba „świętego" (pokładnego), który mogą spożywać tylko kapłani, jak i w wersecie następnym, gdzie Dawid określa swą obecną

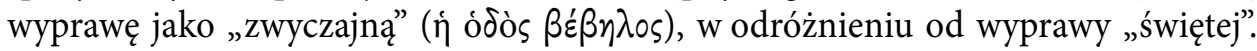

44 Orzeł wprawdzie również jest wymieniony w Pwt 14,11 na liście ptaków, których mięso było zakazane do spożywania, jednak jego skrzydła kilkakrotnie są użyte w ST jako element porównania mającego wydźwięk pozytywny. Tak jest np. w Wj 19,4; Pwt 32,11; Iz 40,31; Ez 17,3.7; Dn 7,4; Prz 23,5. Również w NT spotykamy taki obraz (Ap 4,7; 12,14).

45 Altmann, Banned Birds, 118; por. Aristophanes, Aves 1151-1153.

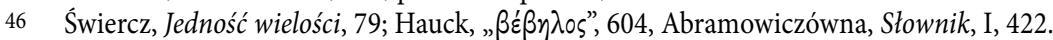

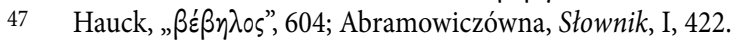


Tak więc w użyciu tego słowa przez tłumaczy LXX nie widać kontekstu misteryjnego czy polemicznego, jest ono traktowane jako neutralne słowo greckie, odpowiadające znaczeniem hebrajskiemu rdzeniu חלל.

W taki sam sposób należy widzieć użycie słowa $\mu$ ía $\mu \alpha$. W języku greckim oznacza ono „plama”, „splamienie” i odnosi się przede wszystkim do nieczystości kultycznej czy rytualnej ${ }^{48}$. W teologii orfickiej $\mu$ ía $\mu \alpha$ określała stan duszy ludzkiej zmieszanej z popiołem spalonych przez Zeusa Tytanów, stan, z którego należało się oczyścić ${ }^{49}$. W greckim tłumaczeniu tekstu hebrajskiego $\mu$ ía $\mu \alpha$ oddaje trzy hebraj-

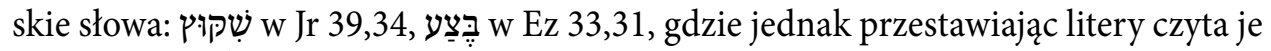

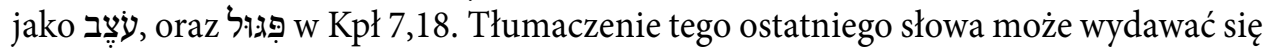
zaskakujące, ponieważ słowo hebrajskie ( $w$ tym i w innych miejscach) określa mięso, które stało się „za stare”, „przedwczorajsze”, a przez to zakazane do spożycia. Ale $\mathrm{z}$ tego powodu to „stare" mięso czyni całą ofiarę splamioną i skażoną, co odpowiada znaczeniu słowa $\mu i \alpha \sigma \mu \alpha^{50}$. Ofiara ta jest jednak odrzucona, a nie przeznaczona do oczyszczenia, trudno więc tu znaleźć jakiekolwiek nawiązanie do orfickiego użycia słowa $\mu$ ía $\sigma \alpha$, należy tu widzieć rzecz skażoną, nienadającą się już więcej do złożenia $\mathrm{w}$ ofierze Bogu, a nie przeznaczoną do oczyszczenia.

Słownictwo misteryjne nie było obce tłumaczom LXX. I nie chodzi tu tylko o podstawowe terminy związane z misteriami, ale również o te bardziej specyficzne, dotyczące ich treści, przesłania czy symboliki. Podane przykłady pokazują, że słownictwo to było przez tłumaczy LXX świadomie i celowo używane. Niejednokrotnie wręcz używali oni terminów greckich, które nie oddawały właściwie tłumaczonych tekstów hebrajskich, a stosując taki zabieg stawiali greckie kulty misteryjne w negatywnym świetle bądź też unikali skojarzeń z misteriami tego, co łączy się z Bogiem i czcią Jego Osoby. Zauważone przypadki każą postawić pytanie, czy takie zabiegi są zjawiskiem marginalnym, czy też tylko przykładami postępowania tłumaczy, które było bardziej powszechne. Zbadane w niniejszej pracy słowa związane z misteriami greckimi to nie jedyne takie słowa obecne w przekładzie Septuaginty, nie mówiąc już o księgach greckich Starego Testamentu. Dlatego ten kierunek badań, analiza innych miejsc Biblii hebrajskiej oddanych w zaskakujący sposób przez słowa greckie odnoszące się do kultów misteryjnych oraz analiza przyczyny zastosowania takich rozwiązań, otwierają kolejne perspektywy badawcze.

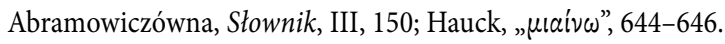

Zarewicz, „O treści tabliczek”, 147.

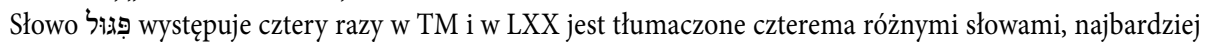
trafnie chyba w Ez 4,14, gdzie jest oddane greckim ह̌ $\omega \lambda$ os, czyli „wczorajszy”, „zepsuty”. 


\section{Bibliografia}

Abramowiczówna, Z. (red.), Słownik grecko-polski. I. A- $\Delta$. II. E-K. III. $\Lambda$-П. IV. P- $\Omega$ (Warszawa: Państwowe Wydawnictwo Naukowe 1957-1966).

Altmann, P., Banned Birds. The Birds of Leviticus 11 and Deuteronomy 14 (Archeology and Bible 1; Tübingen: Mohr Siebeck 2019).

Aristophanes, Aves, tł. pol. A. Sandauer: Arystofanes, Komedie wybrane (red. R. Turasiewicz) (Biblioteka Klasyki Polskiej i Obcej; Kraków: Wydawnictwo Literackie 1977).

Banek, K., „Misteryjne kulty”, Religia. Encyklopedia PWN (red. T. Gadacz - B. Milerski) (Warszawa: Państwowe Wydawnictwo Naukowe 2003) VII, 76-78.

Brzegowy, T., Księga Izajasza. III. Rozdziały 40-66 (Deutero-Izajasz i Trito-Izajasz) (Nowy Komentarz Biblijny. Stary Testament 22/3; Częstochowa: Edycja Świętego Pawła 2019).

Bultmann, R., " $\gamma \iota \omega \omega \sigma \varkappa \omega x \tau \lambda$ ”, Theological Dictionary of the New Testament (red. G. Friedrich) (Grand Rapids, MI: Eerdmans 1972) I, 689-719.

Burkert, W., Starożytne kulty misteryjne, wyd. 3 (Kraków: Tyniec 2014).

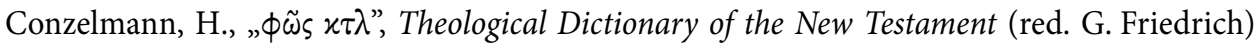
(Grand Rapids, MI: Eerdmans 1972) IX, 310-358.

Doroszewski, F., Orgie słów. Terminologia misteriów w Parafrazie Ewangelii wg św. Jana Nonnosa $z$ Panopolis (Monografie Fundacji na rzecz Nauki Polskiej; Toruń: Wydawnictwo Naukowe UMK 2016).

Driver, S.R. - Gray, G.B., A Critical and Exegetical Commentary on the Book of Job (International Critical Commentary; Edinburgh: Clark 1921).

Drozd, J., „Księga Ozeasza”, Księgi proroków mniejszych: Ozeasza, Joela, Amosa, Abdiasza, Jonasza, Micheasza: wstęp, przekład z oryginału, komentarz (red. S. Łach) (Pismo Święte Starego Testamentu 12/1; Poznań: Pallottinum 1968) 29-117.

Harper, W.R., A Critical and Exegetical Commentary on Amos and Hosea (International Critical Commentary; Edinburgh: Clark 1905).

Harvey, A.E., „The Use of the Mistery Language in the Bible”, The Journal of Teological Studies 31 (1980) 320-336.

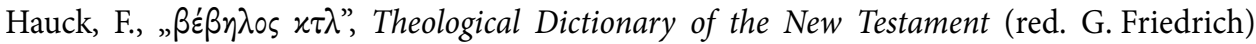
(Grand Rapids, MI: Eerdmans 1972) I, 604-605.

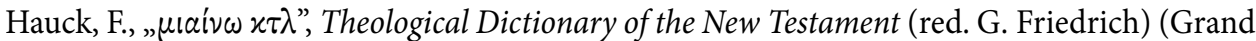
Rapids, MI: Eerdmans 1972) IV, 644-647.

Homa, K., „Misteria eleuzyńskie według Arnobiusza z Sicca. Wersja orficka, homerycka czy afrykańska?", Littera Antiqua 4 (2012) 113-139.

Homerski, J., „Księga Zachariasza”, Księgi proroków mniejszych: Nahuma, Habakuka, Sofoniasza, Aggeusza, Zachariasza, Malachiasza: wstęp, przekład z oryginału, komentarz (red. S. Łach) (Pismo Święte Starego Testamentu 12/2; Poznań: Pallottinum 1968) 237-459.

Kerényi, K., Eleusis. Archetypowy obraz matki i córki (Kraków: Homini 2014).

Koehler, L. - Baumgartner, W. - Stamm, J.J., Wielki słownik hebrajsko-polski i aramejsko-polski Starego Testamentu. I. Słownik hebrajsko-polski ע-א. II. Słownik hebrajsko-polski ת-פ, słownik aramejsko-polski (Warszawa: Vocatio 2008) (= HALOT)

Kolankiewicz, L., „Eleusis: oczy szeroko zamknięte”, Między teatrem a literaturą (red. A. Juzwenko - J. Miodek) (Wrocław: Towarzystwo Przyjaciół Ossolineum 2004) 31-91. 


\section{PAWE LASEK}

Laskowski, Ł., „Niektóre aspekty polemiki Septuaginty z kultami misteryjnymi”, Biblical Annals 4 (2014) 331-354.

Lengauer, W., „ «Hieroi logoi»: tajne nauki starożytnych Greków?”, Ars Regia 1(1993) 13-34.

Lurker, M., Słownik obrazów i symboli biblijnych (Poznań: Pallottinum 1989).

Mitchell, H.G. - Smith, J.M.P. - Bewer, J.A., A Critical and Exegetical Commentary on Haggai, Zechariah, Malachi and Jonah (International Critical Commentary; Edinburgh: Clark 1912).

Muraoka, T., A Greek-Hebrew/Aramaic Two-way Index to the Septuagint (Louvain - Paris Walpole, MA: Peeters 2010).

Nowaszczuk, J., „W kręgu religijności antycznej - misteria eleuzyjskie. Od mitu do kultu”, Colloquia Theologica Ottoniana 1 (2014) 177-202.

Packer, J.I. - Tenney, M.C. (red.), Słownik tła Biblii (Warszawa: Vocatio 2007).

Paganini, M.C.D., „Greek and Egyptian Associations in Egypt: Fact or Fiction?”, Hellenism and the Local Communities of the Eastern Mediterranean: 400 BCE-250 CE (red. B. Chrubasik D. King) (Oxford: Oxford University Press 2017) 131-154.

Rengstorf, K.H., „ $\gamma \varepsilon \lambda \alpha \dot{\omega} \chi \tau \tau \lambda$ ”, Theological Dictionary of the New Testament (red. G. Friedrich) (Grand Rapids, MI: Eerdmans 1972) I, 658-662.

Schneider, S., Rzut oka na dzieje orfiki w starożytności i w nowszych czasach (Kraków: Akademia Umiejętności 1904).

Sfameni Gasparro, G., Misteri e teologie: per la storia dei culti mistici e misterici nel mondo antico (Cosenza: Giordano 2009).

de Sousa, E., „O mirto em Eleusis”, Humanitas 3 (1950-1951) 293-299.

Strzałkowska, B., „Księga Ozeasza w Septuagincie”, Collectanea Theologica 86 (2016) 77-102.

Świderkówna, A., Bogowie zeszli z Olimpu. Bóstwo i mit w greckiej literaturze świata hellenistycznego (Warszawa: Państwowe Wydawnictwo Naukowe 1991).

Świercz, P., Jedność wielości. Świat, człowiek, państwo w refleksji nurtu orficko-pitagorejskiego (Katowice: Wydawnictwo Uniwersytetu Śląskiego 2008).

Tronina, A., Księga Hioba (Nowy Komentarz Biblijny. Stary Testament 15; Częstochowa: Święty Paweł 2013).

Trzcionkowski, L., „Orfizm”, Religia. Encyklopedia PWN (red. T. Gadacz - B. Milerski) (Warszawa: Państwowe Wydawnictwo Naukowe 2003) VII, 437-439.

Trzcionkowski, L., „Z archeologii symbolu: «Symbola» orfików”, Pamiętnik Literacki 106/4 (2015) 113-131.

Trzcionkowski, L. - Wójtowicz, H., „Misteria”, Encyklopedia katolicka (red. E. Ziemann et al.) (Lublin: Towarzystwo Naukowe KUL 2008) XII, 1262-1264.

Wojciechowski, M., Wpływy greckie w Biblii (Kraków: WAM 2012).

Zarewicz, D., „O treści tabliczek i misteriów orfickich”, Humanistyka i Przyrodoznawstwo 16 (2010) 145-166.

Zarewicz, D., „Muzaios, Orfeusz, wyrocznie, misteria w Eleusis - wybrane aspekty”, Humanistyka i Przyrodoznawstwo 19 (2013) 375-385. 